UDC 624.157

\title{
METHOD OF FORECASTING THE TERMS OF SETTLING OF STRUCTURES ON SOILS WITH SILT LAYERS
}

\author{
Oksen Yevhen ${ }^{1 *}$ \\ ${ }^{1} \mathrm{SE}$ «State Research Institute of Building Constructions» https://orcid.org/0000-0003-1075-6840 \\ *Corresponding author E-mail: eioksen@gmail.com
}

\begin{abstract}
The method of forecasting the size and timing of sedimentation of structures on soils with silt layers, based on the results of field observations, has been developed. It is suggested to use a set of exponential dependencies with a constant component. The algorithm and software for calculation of the envelope by experimental data by a stepwise approximation are developed. The process of consolidation of soils is considered as a combination of simultaneous and independent flow of phases of primary filtration consolidation and secondary consolidation of creep. According to the results of data processing of observations by direct iterative calculations by finding the minimum nonconnectedness by the method of least squares.
\end{abstract}

Keywords: base, silt, structure, precipitation, forecast, size, term, method, calculation

\section{МЕТОДИКА ПРОГНОЗУВАННЯ ТЕРМІНІВ ОСІДАННЯ СПОРУД НА ГРУНТАХ 3 ШАРАМИ МУЛУ}

\author{
Оксень С.I. ${ }^{1 *}$ \\ ${ }^{1}$ ДП «Науково-дослідний інститут будівельних конструкцій» \\ *Адреса для листування E-mail: eioksen@gmail.com
}

\begin{abstract}
Розроблено метод прогнозування величини та термінів осідання споруд на грунтах з шарами мулу, заснований на результатах натурних спостережень. Сформульовані вимоги до залежностей апроксимації процесу консолідації мулів. Запропоновано застосовувати для наближення сукупність експоненційних залежностей з постійною складовою. Розроблено алгоритм та програмне забезпечення для розрахунку огинаючої до експериментальних даних. Процес консолідації грунтів розглянуто як сукупність одночасного і незалежного протікання фаз первинної фільтраційної консолідації і вторинної консолідації повзучості. Апробація розробленої методології здійснено під час спостереження за осіданням масивів-гігантів хвилелому Карантинної бухти Одеського морського порту. Вимірювання поточних значень висоти марок, в якості яких були призначені точки в чотирьох кутах верхньої поверхні кожного 3 масивів-гігантів, здійснювалось тахеометром від площадки контейнерного терміналу з приведенням до висоти рівня моря в акваторії Одеського порту. За результатами обробки даних спостереження прямими ітераційними розрахунками шляхом пошуку мінімальної незв'язаності методом найменших квадратів отримані значення параметрів наближення осідання реперних точок, які відповідають потребам практичного застосування. В якості критерію завершення процесу консолідації запропоновано приймати момент стабілізації значень осідань 3 міліметровою точністю з урахуванням отриманих відхилень. Отримані експериментальні залежності для розрахунків швидкості осідання точок масивів-гігантів. Наведено приклади розрахунку прогнозів величини та термінів осідання огороджувального хвилелому контейнерного терміналу Карантинної бухти. Встановлені терміни завершення процесів консолідації мулоподібних грунтів основи волнолому в місці розташування масивів-гігантів і остаточне положення поверхонь масивів-гігантів. Представлена методологія прогнозу осідання основ з мулоподібними грунтами рекомендується для оцінювання впливу консолідації мулів на осідки елементів конструкції при будівництві та під час експлуатації споруд.
\end{abstract}

Ключові слова: основа, мул, споруда, осідання, прогноз, величина, термін, метод, розрахунок 


\section{Introduction}

Artificial and natural soil deposits, as a rule, represent a combination of several materials, such as sand, silt, clay, gravel or mixtures of different proportions. In this case, the occurrence of individual geological layers of the soil is characterized by a variety of forms and variability of thickness, which is especially manifested for structures of significant size, such as dams and wave breams. Design and construction on soils containing layers of silt of a considerable thickness requires an additional increase in the height of the buildings by the size of the construction lift. At the same time, calculations of settling elements of structures, which will be based on such complex foundations, at the design stage are extremely complicated and are preliminary. Current construction norms [1-3] require their refinement on the basis of field observations of the state of the buildings both at the stages of construction and operation.

Review of research sources and publications

At present, the basic method for calculating the settling of layered bases is a layer-summing method $[1,4-10]$. The method is based on the summation of sedimentation of elementary layers of the base within the compressed layer arising from the loads transferred by the structure. In order to take into account the influence of the geometrical features of the construction, the flat and spatial simulation of deformation processes in soils using PLAXIS, ANSYS, LS-DYNA, Midas, Z-Soil, Phase2 and others [11-15] is also used. In this case, the classical models of deformed solid media are accepted for calculations as well as the mechanical properties of materials of separate layers according to the results of laboratory or field tests [16-18] within the framework of accepted models.

\section{Definition of unsolved aspects of the problem}

Difficulties in taking into account parameters of deformation and viscosity of real soils, such as waterlogged sands, mules, complexity of designation in calculations of the depth of the compressive layer of the base in some cases do not allow to obtain with the necessary accuracy the value of complete settling of the structure and to estimate the development of precipitation in time. Thus, the deformation of the mules, accompanied by the consolidation with the extrusion of the liquid and gaseous phases and the plastic deformation of the solid residue, has so far no analytical description and model representation. Therefore, the development of methods for controlling sedimentation of building elements in the course of construction and methods for forecasting their development in time is an actual scientific task for the construction industry.

\section{Problem statement}

The purpose of the work is to develop a method for forecasting the size and terms of settling of structures on soils with mud layers on the basis of field observations at the stages of construction and operation.

\section{Basic material and results}

1. Characteristics of the consolidation of mulch-like soils
According to DSTU B B.2.1-2-96, multidimensional soils or muds include water-saturated modern sediments mainly in marine waters containing organic matter in the form of plant residues and humus. Usually in a mule, the content of particles less than 0.01 $\mathrm{mm}$ is $30-50 \%$ by weight. Upper layers of sludge have a fairly high value of the coefficient of porosity (more than 0.9) and flowing consistency. When compressed in muddy soils, water filtration takes place, and this consequently leads to filtration consolidation. However, accumulation of muddy soils (sealing) does not stop even after the process of filtration consolidation (when the water pressure is near zero), but continues for a long time due to the creep of the skeleton of the soil.

Consolidation is a process of development in time of fading deformation of the seal in compression conditions. Consolidation of soils refers to rheological properties, more precisely to voluminous creep. Bulk creep characterizes the process of time development of volumetric deformations of the soil, which arise in the general case under the influence of average effective stresses on the main axes.

Deformations of volumetric creep developing in the soil in time are:

- fading ones;

- nonlinear ones

as a result of viscous resistance of interbranch connections.

The term «fading deformations» characterizes the presence of the limit of the value of deformation for each value of the existing stresses. Compatible with the term «nonlinear» and «fading deformations» indicate that, for fixed load conditions, the deformation curve of the mules in time has the character of asymptotic approximation to the horizontal line, which is the strain point for a specific base containing layers of mules.

Load conditions are given:

- mode - the time of transfer of the load on the element of the soil and the time of its holding;

- conditions for squeezing porous water from the soil element - with the ability to squeeze porous water (open circuit) and with the conditions under which spin-off porous water is excluded (closed circuit).

During volumetric creep, due to the seal of the soil element, the volume of the soil particle itself decreases by squeezing out pores as liquids and displacement of porous air. Therefore, in general, volumetric creep can develop in both dry and wet soils, in lime and frozen, in rocky and dispersed soils. When compressing muddy soils there is a coherent flow of the following processes:

- filtration consolidation;

- formation of solid precipitation in time;

- creep of the skeleton of the mineral component;

- mineralization of organic impurities of mules,

- the manifestation of which must be considered together.

Consolidation is a partial type of volumetric creep of soil and it may be natural when soils are compacted under the weight of the layers located above as a result of natural accumulation during a certain geological time. 
During the construction work to improve bearing capacity in the bases, form the conditions for the formation of artificial consolidation of the mules, which in the term proceeds much faster than natural (but significantly slower than in laboratory tests of samples).

Consolidation of muds as multiphase soils (Fig. 1) is related to the interaction of solid 1, liquid 2 and gaseous 3 soil constituents, changes in their ratio in space and time as a result of the course of a complex of physicochemical processes (thixotropic hardening, aging, etc.).

In the general case [19-22], the consolidation process can consist of four phases (Figure 2):

- phase $A B$ - prefiltration consolidation, during which the pressure of the fluid begins to exceed the initial value. The phase ends with the formation of closed pores from liquid and gas (see Fig. 1);

- phase $B C$ - primary filtration consolidation, which is carried out by pushing out the pores of liquid and gas from the deformed volumes (Fig. 3);

- phase $C D$ - secondary filtration consolidation, which is carried out by squeezing the bound fluid;

- phase $D E$ - consolidation of volumetric creep, which is carried out due to plastic deformations of the soil skeleton (silt).

a)

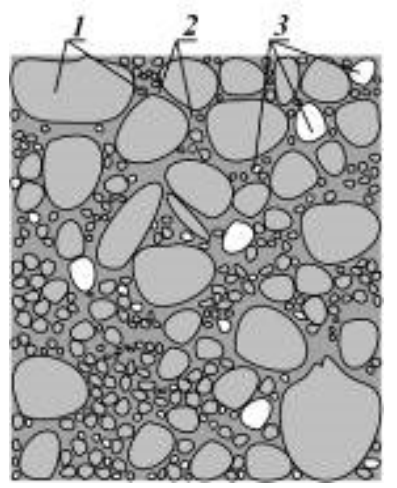

b)

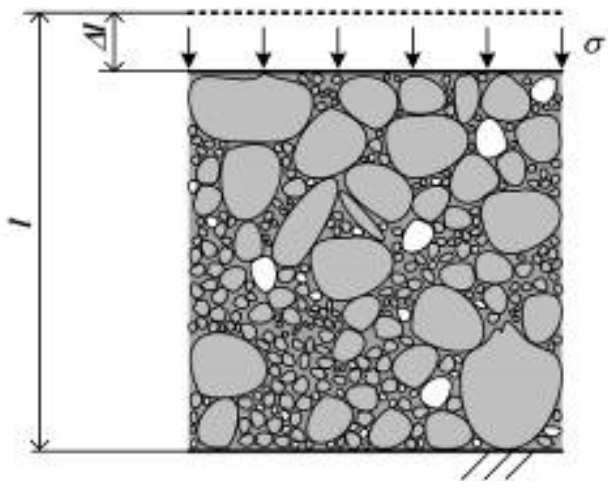

Figure 1 - The scheme of consolidation of mules at the micro level:

a - the components of mudlike soils:

1 - solid; 2 - liquid; 3 - gaseous;

$\mathrm{b}-$ the consolidation scheme at the micro level

When conducting laboratory tests of samples of moles for determining bearing capacity, the process of consolidation of soils is sometimes characterized by indicators of only two phases [22]:
- primary filtering consolidation - coefficient of filtration (primary) consolidation $c_{v}$;

- secondary consolidation of creep - coefficient of bulk (secondary) consolidation $c_{a}$.

Taking into account the simultaneous phases of the process, the description of the consolidation process is sufficiently fully disclosed by the application of two coefficients of consolidation $-c_{v}$ and $c_{a}$.

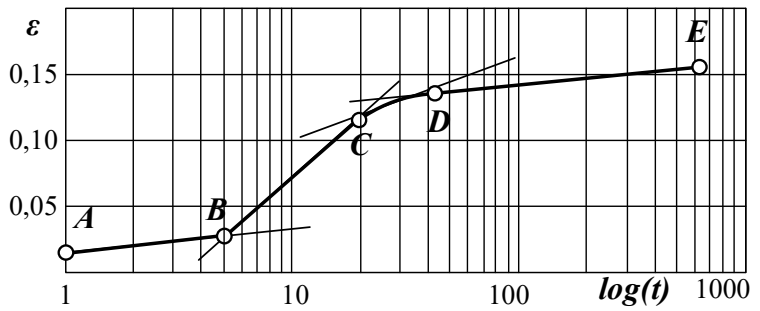

Figure 2 - Phases of consolidation of muds

For presentation of the results of the analysis of the process of consolidation (see Fig. 3), as laboratory samples of mules and structures of bases containing layers of mules, two forms of diagrams are used:

- diagrams of the deformation of the sample (design) in time

$$
\Delta h=f_{1}(t),
$$

where $\Delta h$-deformation of the sample (design), m; $t$-time of observation (during laboratory tests time is measured in minutes, with observation of structures in days);

- diagrams of change in height (length) of a specimen (construction) in time

$$
h=f_{2}(t),
$$

where $h$ - the current value of the height of the sample (design), $\mathrm{m}$.

Taking into account that during initial laboratory tests, the initial height of the specimen $H$ is fixed, and the deformation of the specimen by definition

$$
\Delta h=H-h,
$$

then the diagrams (1) and (2) are equivalent.

In case of need the deformations are given in relative form, and the axis of time, taking into account the longterm processes, is laid out on a logarithmic scale, that is, in the form of diagrams on a semi-logarithmic scale. So, in Fig. 2 diagram of consolidation phases of mules is given on a semi-logarithmic scale.

2. Models of consolidation process of soil bases containing layers of mules

According to the characteristics of the process of consolidation of muds when approximating the results of monitoring of the settling of structures located on moldy soils, approximating dependencies must meet the following requirements:

- have a nonlinear appearance;

-wear fading character - the character of the asymptotic approximation to the horizontal line;

- have a significant change in the intensity of fading over time. 
a)

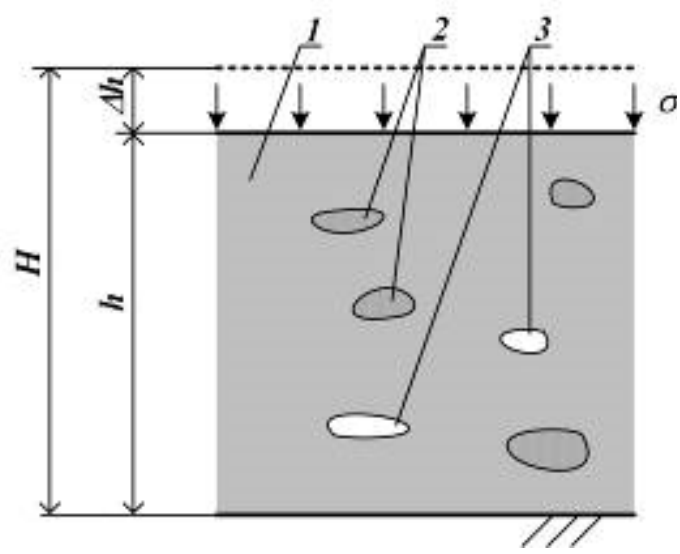

b

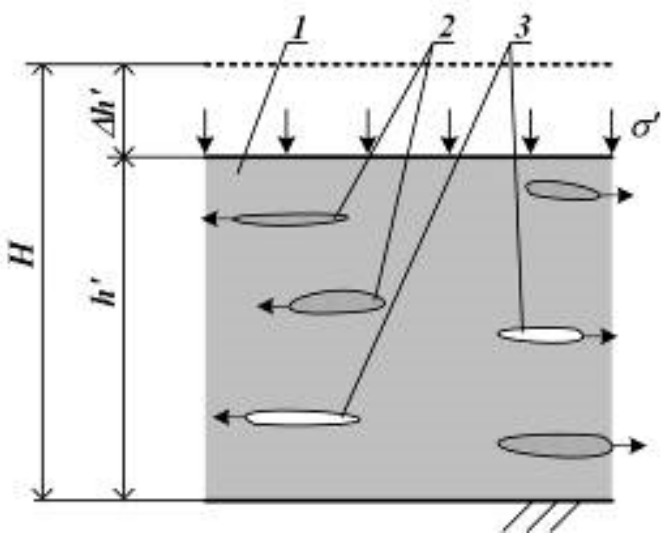

Figure 3 - The scheme of consolidation of mules at the macro level: $\mathrm{a}$ - prefiltration consolidation; $\mathrm{b}$ - filtration consolidation;

1 - a silt of a homogeneous structure;

2 - pores of liquid; 3 - gas pores

The specified requirements correspond to the form of a set of exponents with a constant component

$$
h(t)=\sum_{i=1}^{n} A_{i} e^{-B_{i} t}+h_{0}
$$

where they are constant $A_{i}, B_{i}$ and $h_{0}$ determined when approaching experimental data sets.

The connection of the mathematical dependence (3) to the physical content consists in the distribution of the consolidation of the mules into processes that proceed rather quickly, intensively (components $\sum_{i=1}^{n} A_{i} e^{-B_{i} t}$ ), and on long-term processes $\left(A_{i} e^{-B_{i} t}\right)$ so, that they coincide in time with the limit of deformation of a concrete basis, which contains layers of mules (component).

The number of exponents in the approximating dependence is established on the basis of experimental data in accordance with the nature of the processes oc- curring. In order to predict the processes of sedimentation of organo-mineral soils in the result of consolidation, it is expedient to adopt $n=2$, that is, to take for the approximation of the results of the observation curve

$$
h(t)=a e^{-b t}+c e^{-d t}+h_{0} .
$$

At the same time, for processes that proceed fairly quickly, let us consider the phases of consolidation:

- the phase $A B$ - prefiltration consolidation;

- the phase $B C$ - the primary filtration consolidation.

The remaining phases:

- phase $C D$ - secondary filtration consolidation;

- phase $D E$ - consolidation of volumetric creep,

can be attributed to long-lasting consolidation processes of silt.

To the disadvantages of using the dependence (4) to approximate the consolidation processes of the mules should be attributed:

- a significant number of unknown approximation parameters - five constant $a, b, c, d$ and $h_{0}$;

- transcendence of function (4).

The indicated disadvantages considerably complicate the process of calculation of approximation parameters and do not allow to obtain the result in an explicit form.

The calculation of the approximation parameters $a, b, c, d$ and $h_{0}$ can be done by direct iterative calculations by finding the minimum irreconcilability - the method of least squares.

3. Algorithm for calculation of terms of development of settling elements of structures

The procedure for calculating the terms for the deposition of the elements of buildings will be considered on the example of the construction of a fencing container terminal at the Quarantine Mole of the Odesa branch of the State Enterprise "AMPU» (Fig. 4) in the unfavorable natural conditions of the site (the presence of a large thickness of silts) and the requirements of observance of measures to reduce sediment and compensate for their impact for construction

3.1 Situational plan for the location of the object. The indigenous bed of the district of the port facilities is represented by Tertiary meiotic and Upper Sarmatian deposits, composed of gray and red varieties of clay with layers and sand lenses.

At the base of the enclosing wavy container terminal there is light semi-solid clay 7 with layers of sand 8,9 , loams, and from the surface of the natural deposits are covered with different composition of the bulk soils of alluvial-sea genesis 6, and in its area - a complex of estuarine or alluvial-marine sediments. Seismicity of the construction area is 7 points. The category of grounds of the site for seismic properties is III. Gigantic massifs are located on stone pouring 3 from layers of crushed stone with a thickness of 40-70 mm and a stone with a mass of $15-100 \mathrm{~kg}$ and a layer of sand 5. To increase the strength of the structure reinforced by layers of geogrid 2 and nonwoven geotextile material 4. 


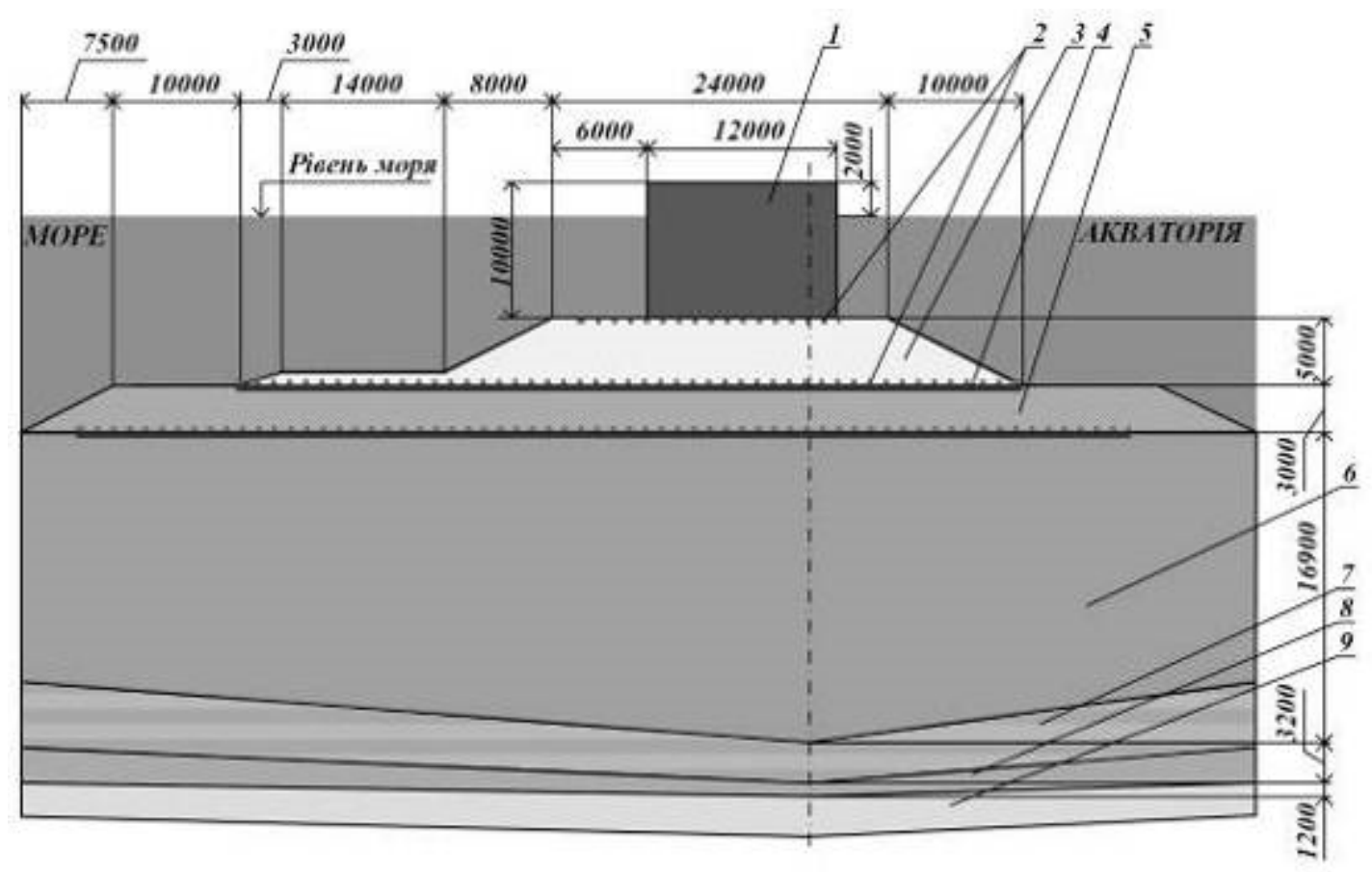

Figure 4 - Scheme of intersection of the waveguide in the zone of the massive-giant No. 3: 1 - massive giant; 2 - geogrid; 3 - stone mound; 4 - non-woven geotextile material; 5 - sand; 6 - gray silt; 7 - clay is light, fluid-plastic; 8 - dust of sand grain density; 9 - sand of medium size, medium density

3.2. Observation results of precipitation. After the completion of the first stage of construction, the control over the settling of massive-giants was carried out. Bottom line points are installed on each of the four corners of the giant array. The reference point number consists of a giant massive number and a corner number that is set from the right lower corner counterclockwise in accordance with the top view of the giant array from the container terminal's water area. Measurement of the height of the reference points was carried out by the tacheometer from the platform of the container terminal with bringing to the sea level.

Diagrams of subsidence of reference points 31 and 32 of the giant massif No. 3 relative to the sea level during the observation period are shown in Fig. 5 in normal $h_{i j}=f(t) \quad$ (Fig. 5a) and semi-logarithmic $h_{i j}=f(\log (t))$ (Fig. 5b) scales. As a unit, the measured time we assign one day - «day». As follows from the charts in the semilogarithmic scale, the fixed subsidence of the reference points in time is sequentially grouped with respect to the set of straight lines 1,2 and 3 . Since the straight lines on the semilogarithmic diagram correspond to the exponential curves on the charts with normal scales, this provides a basis for the approach of the sedimentation process to dependences in the form aggregate of exponents.

3.3 Dependency choice for approximation. The choice of dependence for approximation is carried out on the basis of the analysis of sedimentation diagrams constructed on a semi-logarithmic scale by allocating sections with a homogeneous character of subsidence in the order, reverse to observation. So, for an example, we consider the dependence (4) as an approximating one. The areas of stable precipitation 3 (see Fig. 5b) will be approximated by the component $a e^{-b t}$, and the areas of the initial (intense) precipitation 1 and 2 - by the component $c e^{-d t}$. We assign the length of the vectors of intensive precipitation to $M=17$, the vectors of stable precipitation $N=6$ at the total length of the vectors in the 23 observations. In case of need for a more detailed description of the initial settling stage, we may consider sections 1 and 2 separately by adopting $n=3$ and introducing an additional component $l e^{-m t}$ . However, this would require an increase in the measurement of sediment during observation so that the number of points in each plot to be approximated is not less than 4-5 (at areas 1 only three measurements are available).

3.4 Approximation of the stable subsidence area. We perform the approximation of the vector of the stable subsidence of plot 3 (see Fig. 5a) with the length $N$ of the approximation dependence

$$
h s t(t)=a e^{-b t}+h_{0}, .
$$

According to the input data, we assign:

- vector of time $x_{i}=t_{i+N}$;

- vector of settlements $y_{i}=h_{i+N}$.

As a criterion for completing the approximation process, we assign the smallest sum of the squares of the difference between the values of the approximating dependence and the measurement data $y_{i}=h_{i+N}$.

Below is the text of the program for calculating the approximation coefficients of a direct iterative passage in the Matlab programming language: 


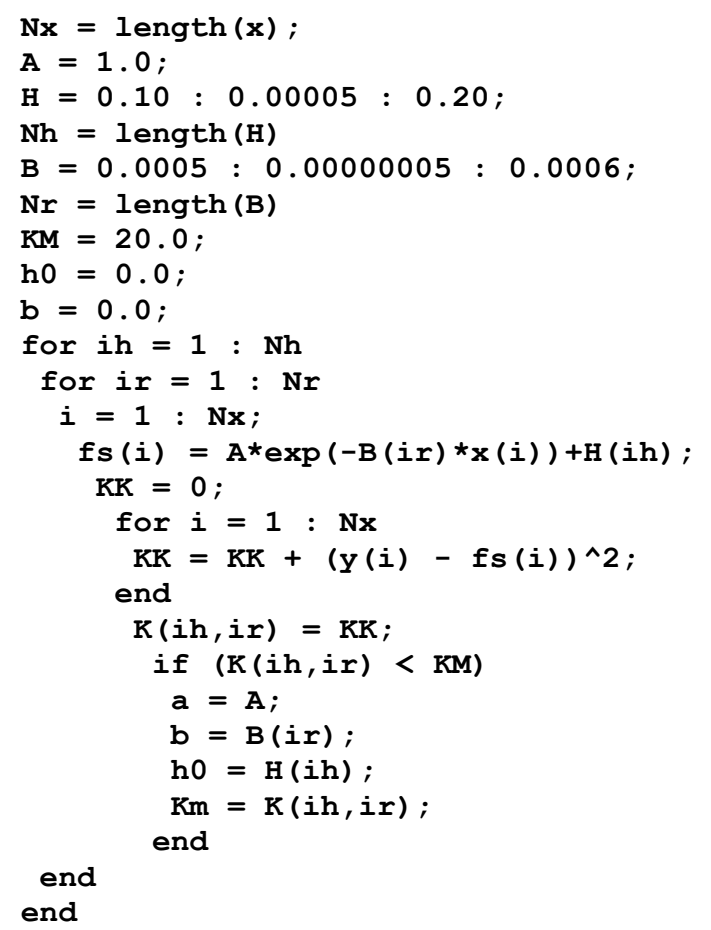

As a result of the execution of the program, the solution is obtained in the form of values $a, b$ and $h_{0}$ at which the minimum value is achieved. The results of calculations for reference points 31 and 32 are shown in Table 1.

a)

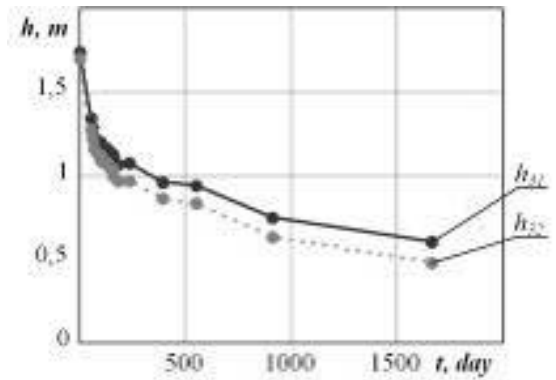

b)

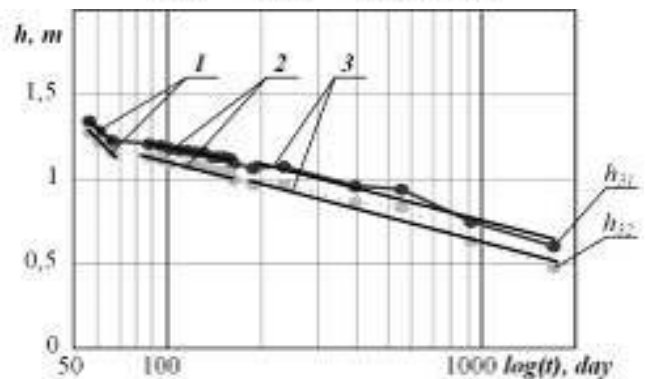

Figure 5 - Diagram of subsidence

of reference points of massive-giant No.3:

$\mathrm{a}$ - normal scale; $\mathrm{b}$ - semilogarithmic scale;

$h_{31}$ - reference point $31 ; h_{32}$ - the reference point 32 .

3.5 Determination of the vector of intense subsidence of reference points. The procedure for determining the vector of intense settling is carried out for experimental data in the reverse order of time «from stable to intense». According to Dependence (4), the vector of intensive subsidence of reference points in length $M$ can be calculated as

$$
\operatorname{hin}_{i}=h_{i}-h s t(t)=h_{i}-a e^{-b t}+h_{0},
$$

Since the approximation of the intensive deposition vectors will be exponential-dependent without a constant component

$$
\operatorname{hin}(t)=c e^{-d t},
$$

then for the calculation of approximation coefficients it is expedient to apply standard experimental data processing programs, for example, Curve Fitting Tools Matlab software package. The results of the calculations of the coefficients $c, d$ and the sum of the squares of the difference $\mathrm{Km}$ for the reference points 31 and 32 are shown in Table 2.

3.6 Diagram and forecast of subsidence of reference points. The result of the procedures performed are dependencies (4) whose approximation coefficients for the example under consideration are given in Table 1 and Table 2. Comparison of experimental data with approximations of reference points of massive-giant No. 3 is shown in Fig. 6 a.

Table 1 - Parameters of the approaching plot of stable settling of reference points 31 and 32 of the massive-giant No. 3

\begin{tabular}{|l|l|c|c|c|}
\hline $\begin{array}{c}\text { The refe- } \\
\text { rence point }\end{array}$ & $a, \mathrm{~m}$ & $b, 1 /$ day & $h_{0}, \mathrm{~m}$ & $K m, \mathrm{~m}^{2}$ \\
\hline 31 & 1.0 & $0.5308 \cdot 10^{-3}$ & 0.1722 & $3.893 \cdot 10^{-3}$ \\
\hline 32 & 1.0 & $0.5899 \cdot 10^{-3}$ & 0.0862 & $2.659 \cdot 10^{-3}$ \\
\hline
\end{tabular}

Table 2 - Parameters of approaching the intensive settling area of reference points 31 and 32 of the massive-giant No. 3

\begin{tabular}{|c|c|c|c|}
\hline $\begin{array}{c}\text { The refe- } \\
\text { rence point }\end{array}$ & $c, \mathrm{~m}$ & $d, 1 /$ day & $K m, \mathrm{~m}^{2}$ \\
\hline 31 & 0.5640 & 0.02131 & 0.004420 \\
\hline 32 & 0.6089 & 0.02019 & 0.004737 \\
\hline
\end{tabular}

Average-quadratic deviation of extrapolation dependencies with respect to experimental data calculated as

$$
d e l=\sqrt{\frac{\sum_{i=1}^{2} K m_{i}}{N+M}}
$$

$0.019 \mathrm{~m}$ and $0.021 \mathrm{~m}$ for reference points 31 and 32 , respectively. The obtained mean-square deviation values fully correspond to the needs of practical application and indicate that the process of subsidence of the massif-giant can be approximated by the dependence in the form of a set of exponents with a constant component.

After substitution $T=365 t$ of dependence (4) can be used to predict the subsidence of reference points by extrapolation (Fig. 6b). As a criterion for completing the process, it is advisable to take a moment of stabilization of the values of sediment, for example, taking into account the deviations received (8) the stabilization of the third sign. Thus, it has been established that consolidation processes of mud-like grounds of the waveguide at the location and deposition of the massive-giant No. 3 for reference points 31 and 32 will end, respectively, for 35 years and 38 years from the commencement of operation (from 05/21/2014). The height 
of the location of the reference points 31 and 32 will then be $0.173 \mathrm{~m}$ and $0.088 \mathrm{~m}$ respectively above sea level.

a)

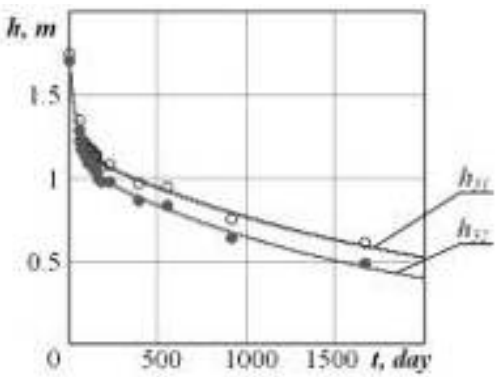

b)

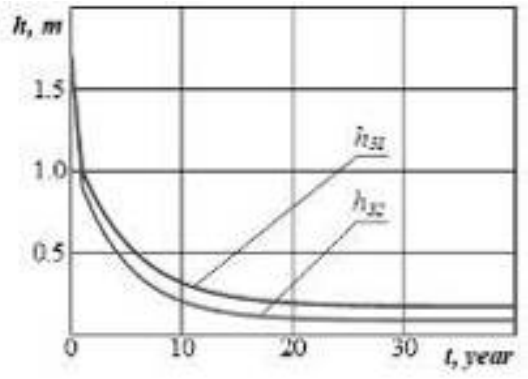

Figure 6 - The forecast of subsidence of the reference points of the massive-giant No. 3:

$\mathrm{a}$ - comparison of experimental data with approximations; $b$ - extrapolation dependencies;

$h_{31}$ - reference point $31 ; h_{32}$ - the reference point 32 .

3.7 Speed of subsidence of reference points. Taking into account that dependences (3) link the subsidence of construction points with time, on their basis, by differentiation, equations can be constructed to calculate the rate of subsidence of points as

$$
v h(t)=\frac{d\left(\sum_{i=1}^{n} A_{i} e^{-B_{i} t}+h_{0}\right)}{d t}=-\sum_{i=1}^{n} A_{i} B_{i} e^{-B_{i} t},
$$

or for a partial case of dependence (3) as

$$
v h(t)=-\left(a \cdot b \cdot e^{-b t}-c \cdot d \cdot e^{-d t}\right) .
$$

Diagrams of velocity of subsidence of reference points of massive-giant № 3 are shown in Fig. 7

Numerical values of the rate of subsidence of reference points when connected with the thickness of the layers of sludge and loading on the soil basis can be applied during the observation of the state of the building as a control for assessing the nature of the development of sedimentation.

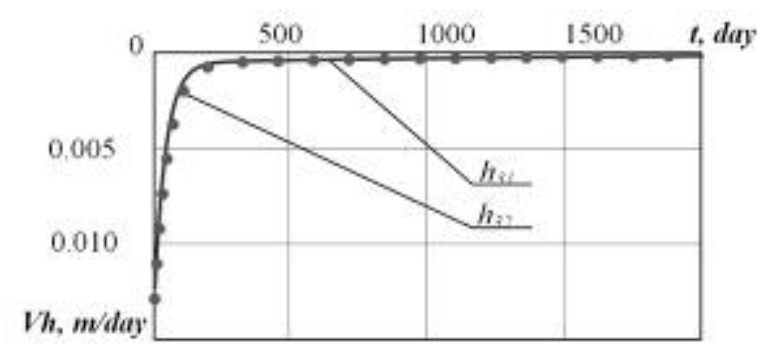

Figure 7 - The rate of subsidence of the reference points of the massive giant No. 3: $h_{31}$ - reference point $31 ; h_{32}$ - the reference point 32 .

\section{Conclusions}

1. The development in time of processes of consolidation of muds, silty and organo-mineral soils and settling of structures constructed on bases with such layers, is exponential in nature and can be approximated by the dependence in the form of a set of exponentials with a constant component.

2. A method for predicting the size and terms of settling of structures on soils with mud layers, based on the results of field observations, has been developed. As an approximative it is suggested to apply a set of exponential dependencies with a constant component. The algorithm and software for calculation of enveloping to experimental data by a step-by-step approach are developed. An example of the calculation of the forecast of the size and terms of settling of the enclosing wavy container terminal on the Quarantine Mole of the Odesa branch of the State Enterprise «AMPU» is given.

3. Direct iterative calculations by finding the minimum non-relation by the method of least squares have established the parameters of dual exponential dependence with the constant for forecasting the subsidence of reference points of the massif-giant No. 3. It was established that the processes of consolidation of the moldlike soils of the basis of the waveguide at the location and deposition of the massive giant No. 3 for reference points 31 and 32 will be completed, respectively, for 35 years and 38 years from the beginning of operation (from 21.05.2014). The height of the location of the reference points 31 and 32 will then be $0.173 \mathrm{~m}$ and 0.088 $\mathrm{m}$ respectively above sea level.

4. The proposed methodology for forecasting the settling of bases with multidimensional soils is recommended for assessing the effect of consolidation of muds on the remains of structural elements during construction and during the operation of structures.

\section{References}

1. ДБН В.2.1-10-2009. (2009). Основи та фундаменти споруд. Основні положення проектування. Київ: Мінрегіонбуд України.

2. ДБН В.2.4-3:2010. (2010). Гідротехнічні споруди. Основні положення. Київ: Мінрегіонбуд України.

3. ДБН В.1.2-5:2007. (2007). Науково-технічний супровід будівельних об'єктів. Київ: Мінрегіонбуд України.

4. Далматов, Б.И. (1988). Механика грунтов, основания и фундаменты. Ленинград: Стройиздат.

5. Корнієнко, М.В. (2009). Основи і фундаменти. Київ: КНУБА.
1. DBN B.2.1-10-2009. (2009). Foundations and foundations of structures. Basic design principles. Kyiv: Ministry of Mining and Construction of Ukraine.

2. DBN B.2.4-3: 2010. (2010). Waterworks. Substantive provisions. Kyiv: Minregion of Ukraine.

3. DBN B.1.2-5:2007. (2007). Scientific and technical support against construction sites. Kyiv: Minregion of Ukraine.

4. Dalmatov, B.I. (1988). Soil mechanics, foundations and foundations. Leningrad: Stroyizdat.

5. Kornienko, M.V. (2009). Fundamentals and Foundations. Kyiv: KNUBA. 
6. Зоценко, М.Л., Коваленко, В.І., Яковлєв, А.В., Петраков, О.О., Швець, В.Б., Школа, О.В., Біда, С.В., Винников, Ю.Л. (2004) Інженерна геологія. Механіка грунтів, основи та фундаменти. Полтава: ПНТУ.

7. Ухов, С.Б., Семенов, В.В., Знаменский, В.В. и др. (2007). Механика грунтов, основания и фундаменты. Москва: Высшая школа.

8. Соломин, В.И., Гаврилюк, В.В. (2007). Анализ методов расчёта осадки фундаментов мелкого заложения. Вестник ЮУрГУ, 22, 64-66.

9. Desai, C.S. \& Christian, J.T. (1977). Numerical methods in geotechnical engineering. New York: McGraw-Hill.

10. Das, Braja M. (2008). Advanced soil mechanics. New York: Taylor \& Francis Group.

11. Болдырев, Г.Г., Муйземнек, А.Ю., Малышев, И.М. (2016). Моделирование дефомачионных проиессов 6 грунтах с использованием программ ANSYS и LS-DYNA. Геотехника, 4, 58-74.

12. Вавринюк, Т.С., Федоренко, Е.В. (2014). Результаты инженерных изысканий, как основа для расчетов транспортных сооружений. Инженерные изыскания, 3 , 46-49.

13. Федоренко, Е.В. (2013). Геотехнические расчеты конструкиий земляного полотна $c$ применением геосинтетических материалов // Х Научно-техническая конференция «Чтения, посвященные 109-летию профессора Г. М. Шахунянца» (Москва, МИИТ), 66-68.

14. Li, S. \& Liu, W.K. (2000). Numerical simulation of strain localization in inelastic solids using mesh-free methods. Int. J. for Numerical Methods in Engineering, 48, 12851309.

15. Murakami, A., Arimoto, S., Setsuyasu, T. \& Nishiyama, T. (2005). Mesh-Free Method for Predicting the Behavior of Saturated Soil. Geomechanics. Testing, Modelling, and Simulation, 664-672.

16. Баданин, А.Н., Нурумбаева, Л.М. (2013). Особенности современного расчета фундаментов по II группе предельных состояний. Строительство уникальных зданий и сооружений, 4(9), 36-41.

17. Ляшенко, П.А., Денисенко, В.В. (2008). Расчет осадки основания фундамента по микроструктурной модели грунта. Труды Международной конференции по геотехнике «Развитие городов и геотехническое строительство», 193-197.

18. Ляшенко, П.А., Денисенко, В.В. (2009). Расчет осадки основания фундамента по результатам испытания штампом. Научный журнал КубГАУ, 47(3), 83-92.

19. ДСТУ ISO/TS 17892-5:2008. (2008). Геотехнічні дослідження та випробування. Ч. 5. Лабораторні одометричні випробування трунту з прирощуванням навантаження (ISO/TS 17892-5:2004, IDT).

20. ДСТУ CEN ISO/TS 17892-7:2007. (2007). Геотехнічні дослідження та випробування. Лабораторні дослідження трунту. Ч. 7. Дослідження необмежуваного опору стисканню дрібнозернистих трунтів (CEN ISO/TS 17892-7:2004, IDT).

21. ДСТУ ISO/TS 17892-9:2008. (2008). Геотехнічні дослідження та випробування. Ч. 9. Лабораторні консолідовані тривісні випробування трунту, насиченого водою, на стискуваність (ISO/TS 17892-9:2004, IDT).

22. ГОСТ 12248-2010. (2012). Грунты Методы лабораторного определения характеристик прочности и деформируемости. Москва: Стандартинформ.
6. Zotsenko, M.L., Kоvalenко, V.I., Jakovlev, A.V., Petrakov, O.O., Shvets, V.B., Shkola, O.V., Bida, S.V., Vynnykov, Y.L.. Engineering geology. Soil mechanics, bases and foundations: Textbook Poltava: PNTU.

7. Ukhov, S.B., Semenov, V.V., Znamensky, V.V. et al. (2007). Soil mechanics, foundations and foundations. Moscow: High School.

8. Solomin, V.I., Gavrilyuk, V.V. (2007). Analysis of methods for calculating sedimentation of shallow foundations. Bulletin of USU, 22, 64-66.

9. Desai, C.S. \& Christian, J.T. (1977). Numerical methods in geotechnical engineering. New York: McGraw-Hill.

10. Das, Braja M. (2008). Advanced soil mechanics. New York: Taylor \& Francis Group.

11. Boldyrev, G.G., Muyznemek, A.Yu., Malyshev, I.M. (2016). Modeling of soil deformation processes using ANSYS and LS-DYNA software. Geotechnics, 4, 58-74.

12. Vavrynyuk, T.S., Fedorenko, E.V. (2014). The results of engineering research as a basis for the calculation of transport structures. Engineering Research, 3, 46-49.

13. Fedorenko, E.V. (2013). Geotechnical calculations of earthbed structures using geosynthetic materials // X Scientific and Technical Conference "Readings on the 109th Anniversary of Professor GM Shakhunyants" (Moscow, MIIT), 66-68.

14. Li, S. \& Liu, W.K. (2000). Numerical simulation of strain localization in inelastic solids using mesh-free methods. Int. J. for Numerical Methods in Engineering, 48, 12851309.

15. Murakami, A., Arimoto, S., Setsuyasu, T. \& Nishiyama, T. (2005). Mesh-Free Method for Predicting the Behavior of Saturated Soil. Geomechanics. Testing, Modelling, and Simulation, 664-672.

16. Badanin, AN, Nurumbaeva, L.M. (2013). Features of the modern calculation of foundations for the II group of limit states. Construction of Unique Buildings and Structures, 4 (9), 36-41.

17. Lyashenko, PA, Denisenko, V.V. (2008). Calculation of sediment of the base of the foundation by microstructural model of soil. Proceedings of the International Conference on Geotechnics "Urban Development and Geotechnical Construction", 193-197.

18. Lyashenko, PA, Denisenko, V.V. (2009). Calculation of the deposit of the base of the foundation on the results of the stamp test. KubAU Scientific Journal, 47 (3), 83-92.

19. DSTU ISO/TS 17892-5: 2008. (2008). Geotechnical research and testing. Part 5. Laboratory odometric load increment tests (ISO/TS 17892-5: 2004, IDT).

20. DSTU CEN ISO/TS 17892-7: 2007. (2007). Geotechnical research and testing. Laboratory studies of soil. Part 7. Study of unrestricted compression resistance of fine-grained soils (CEN ISO/TS 17892-7: 2004, IDT).

21. DSTU ISO/TS 17892-9: 2008. (2008). Geotechnical research and testing. Part 9. Laboratory console-based triaxial compression testing of soil with water (ISO/TS 17892-9: 2004, IDT).

22. GOST 12248-2010. (2012). Soils Methods for laboratory determination of strength and deformability characteristics. Moscow: Standardinform. 